\title{
Correction to: Rectal indomethacin alone versus indomethacin and prophylactic pancreatic stent placement for preventing pancreatitis after ERCP: study protocol for a randomized controlled trial
}

B. Joseph Elmunzer ${ }^{1 *}$, Jose Serrano ${ }^{2}$, Amitabh Chak ${ }^{3}$, Steven A. Edmundowicz ${ }^{4}$, Georgios I. Papachristou ${ }^{5}$, James M. Scheiman ${ }^{6}$, Vikesh K. Singh7 , Shyam Varadarajulu', John J. Vargo ${ }^{9}$, Field F. Willingham ${ }^{10}$, Todd H. Baron ${ }^{11}$, Gregory A. Coté ${ }^{1}$, Joseph Romagnuolo ${ }^{12}$, April Wood-Williams ${ }^{1}$, Emily K. Depue', Rebecca L. Spitzer', Cathie Spino ${ }^{13}$, Lydia D. Foster ${ }^{14}$, Valerie Durkalski ${ }^{14}$ and on behalf of the SVI study group and the United States Cooperative for Outcomes Research in Endoscopy (USCORE)

Correction to: Trials (2016) 17:120

https://doi.org/10.1186/s13063-016-1251-2

Following publication of the original article [1], the authors identified an error in the author name of Shyam Varadarajulu.

The incorrect author name is: Shyam Varadurajulu

The correct author name is: Shyam Varadarajulu

\section{Author details}

'Division of Gastroenterology and Hepatology, Medical University of South Carolina, MSC 702, 114 Doughty St., Suite 249, Charleston, SC 29425, USA. ${ }^{2}$ Institute of Diabetes and Digestive and Kidney Diseases, National Institutes of Health, Bethesda, MD, USA. ${ }^{3}$ Division of Gastroenterology, University Hospitals Case Medical Center, Cleveland, OH, USA. ${ }^{4}$ Division of Gastroenterology, Washington University School of Medicine, St Louis, MO, USA. ${ }^{5}$ Division of Gastroenterology, Hepatology, and Nutrition, University of Pittsburgh Medical Center, Pittsburgh, PA, USA. 'Division of Gastroenterology, University of Michigan Medical Center, Ann Arbor, MI, USA. ${ }^{7}$ Division of Gastroenterology, Johns Hopkins Medical Institutions, Baltimore, MD, USA. ${ }^{8}$ Center for Interventional Endoscopy, Florida Hospital, Orlando, FL, USA. ${ }^{9}$ Department of Gastroenterology and Hepatology, The Cleveland Clinic Foundation, Cleveland, OH, USA. ${ }^{10}$ Division of Digestive Diseases, Emory
University School of Medicine, Atlanta, GA, USA. ${ }^{11}$ Division of Gastroenterology and Hepatology, University of North Carolina School of Medicine, Chapel Hill, NC, USA. ${ }^{12}$ Tidelands Health, Murrels Inlet, SC, USA.

${ }^{13}$ Department of Public Health, University of Michigan Medical School, Ann Arbor, MI, USA. ${ }^{14}$ Data Coordination Unit, Department of Public Health Sciences, Medical University of South Carolina, Charleston, SC, USA.

Published online: 03 June 2020

\section{Reference}

1. Elmunzer BJ, et al. Rectal indomethacin alone versus indomethacin and prophylactic pancreatic stent placement for preventing pancreatitis after ERCP: study protocol for a randomized controlled trial. Trials. 2016;17:120. https://doi.org/10.1186/s13063-016-1251-2.

The original article can be found online at https://doi.org/10.1186/s13063016-1251-2.

* Correspondence: elmunzer@musc.edu

'Division of Gastroenterology and Hepatology, Medical University of South Carolina, MSC 702, 114 Doughty St., Suite 249, Charleston, SC 29425, USA

Full list of author information is available at the end of the article

C The Author(s). 2020 Open Access This article is licensed under a Creative Commons Attribution 4.0 International License, which permits use, sharing, adaptation, distribution and reproduction in any medium or format, as long as you give appropriate credit to the original author(s) and the source, provide a link to the Creative Commons licence, and indicate if changes were made. The images or other third party material in this article are included in the article's Creative Commons licence, unless indicated otherwise in a credit line to the material. If material is not included in the article's Creative Commons licence and your intended use is not permitted by statutory regulation or exceeds the permitted use, you will need to obtain permission directly from the copyright holder. To view a copy of this licence, visit http://creativecommons.org/licenses/by/4.0/ The Creative Commons Public Domain Dedication waiver (http://creativecommons.org/publicdomain/zero/1.0/) applies to the data made available in this article, unless otherwise stated in a credit line to the data. 